\title{
INHIBITION OF PLATELET AGGREGATION EX VIVO IS REPRESSED IN APOLIPOPROTEIN E DEFICIENT MICE
}

\begin{tabular}{|c|c|}
\hline Journal: & Canadian Journal of Physiology and Pharmacology \\
\hline Manuscript ID & cjpp-2017-0314.R1 \\
\hline Manuscript Type: & Article \\
\hline Date Submitted by the Author: & 21-Jun-2017 \\
\hline Complete List of Authors: & $\begin{array}{l}\text { Carrier, Emilie; University of Sherbrooke } \\
\text { Houde, Martin; University of Sherbrooke } \\
\text { Grandbois, Michel; University of Sherbrooke } \\
\text { Bkaily, Ghassan; Départment d'anatomie et biologie cellulaire, } \\
\text { Warner, Timothy D; Barts and The London School of Medicine and } \\
\text { Dentistry Blizard Institute } \\
\text { D'Orleans-Juste, Pedro; University of Sherbrooke, }\end{array}$ \\
\hline $\begin{array}{r}\text { Is the invited manuscript for } \\
\text { consideration in a Special } \\
\text { Issue? }\end{array}$ & IACS Sherbrooke 2016 special issue Part 1 \\
\hline Keyword: & \\
\hline
\end{tabular}




\section{INHIBITION OF PLATELET AGGREGATION EX VIVO IS REPRESSED IN APOLIPOPROTEIN E DEFICIENT MICE}

É. Carrier ${ }^{* 1}$, M. Houde ${ }^{* 1}$, M. Grandbois ${ }^{*}$, G. Bkaily**, T. D. Warner ${ }^{\dagger}$ and P. D’OrléansJuste $^{*}$

*Departments of Pharmacology and Physiology or **Anatomy and Cell Biology, Faculty of Medicine and Health Sciences, Université de Sherbrooke, Sherbrooke, Québec, Canada. ${ }^{\dagger}$ The William Harvey Research Institute, Barts and the London School of Medicine and Dentistry, Queen Mary University of London, London, UK.

${ }^{1}$ These authors contributed equally to this work.

Running title: Altered platelet inhibition in ApoE deficient mice

Address correspondence to: Dr. Pedro D’Orléans-Juste, Department of Pharmacology and Physiology, Faculté de Médecine et des Sciences de la Santé, Université de Sherbrooke, 3001, 12 ${ }^{\text {th }}$ Avenue North, Sherbrooke, Québec, J1H 5N4, E-mail: labpdj@usherbrooke.ca, Tel.: (819) 564-5344, FAX: (819) 564-5400 


\begin{abstract}
In the present study, we assessed if the endogenous platelet inhibitory mechanisms are altered in the early to moderate stages of the atherosclerotic process. Apolipoprotein E deficient mice (ApoE-/-), a mouse model of atherosclerosis, and their wild-type (WT) counterparts were used to assess agonist-stimulated synthesis of prostacyclin $\left(\mathrm{PGI}_{2}\right)$, inhibition of platelet aggregation ex vivo and intra-platelet cAMP levels. Basal U46619 and ADP -induced platelet aggregation in vitro were increased in ApoE-/- mice at 18-20 weeks in comparison to 8-10 weeks of age. Systemically administered endothelin-1 (ET-1) or bradykinin (BK) inhibited platelet aggregation in a similar fashion in 8-10 week-old ApoE-/- and WT mice, but not in the ApoE-/- mice at 18-20 weeks of age, although both peptides maintained their capacity to increase plasma levels of the $\mathrm{PGI}_{2}$. Intravenous infusion of $\mathrm{PGI}_{2}$ also failed to inhibit platelet aggregation ex vivo in $18-20$ week old ApoE-/- mice. Interestingly, both $\mathrm{BK}$ and $\mathrm{PGI}_{2}$ retained their ability to increase intra-platelet cAMP in WT and ApoE-/- mice. Our results suggest that a loss of activity of endogenous inhibitory mechanisms could contribute to the increased platelet reactivity in ApoE-/- mice and that this phenomenon occurs early in the intermediate stage of the atherosclerotic process.
\end{abstract}

Key words: Atherosclerosis, mouse, platelet, prostacyclin, bradykinin, cAMP, endothelin-1, endothelium 


\section{RÉSUMÉ EN FRANÇAIS}

Dans la présente étude, nous avons évalué si les mécanismes endogènes d'inhibition de l'agrégation plaquettaire étaient altérés dans les stades précoces et intermédiaires du processus athérosclérotique. Des souris déficientes pour l'apolipoprotéine E (ApoE-/-), un modèle d'athérosclérose, et leurs congénères de type sauvage (WT) ont été utilisées pour évaluer la synthèse de prostacycline $\left(\mathrm{PGI}_{2}\right)$ stimulée par des agonistes, l'inhibition de l'agrégation plaquettaire ex vivo et les niveaux d'AMPc intra-plaquettaire. Dans les souris ApoE-/-, l'agrégation plaquettaire basale induite par l'ADP ou l'U46619 est augmentée à l'âge de 18-20 semaines comparativement à 8-10 semaines. L'administration systémique d'endothéline-1 (ET-1) ou de bradykinine (BK) a inhibé l'agrégation plaquettaire de façon similaire chez les souris ApoE-/- de 8-10 semaines et les souris WT, mais pas chez les souris ApoE-/- âgées de 18-20 semaines, alors que les deux peptides ont préservé leur capacité d'augmenter les niveaux plasmatiques de $\mathrm{PGI}_{2}$. L'infusion intraveineuse de $\mathrm{PGI}_{2} \mathrm{n}$ 'a pas inhibé l'agrégation plaquettaire ex vivo chez les souris ApoE-/- de 18-20 semaines. Par contre, la BK et la $\mathrm{PGI}_{2}$, ont conservé leur capacité d'augmenter les niveaux d'AMPc intra-plaquettaire dans les souris WT et ApoE-/-. Nos résultats suggèrent que la perte d'activité des mécanismes inhibiteurs endogènes pourrait contribuer à l'augmentation de la réactivité plaquettaire dans les souris ApoE-/- et que ce phénomène apparaît tôt dans le stade intermédiaire du processus athérosclérotique.

Mots clés: athérosclérose, souris, plaquette, prostacycline, bradykinine, AMPc, endothéline-1, endothélium 


\section{Introduction}

Atherosclerosis is a complex pathology characterized by plaque formation in arteries due to lipid deposition, immune cell accumulation and intimal thickening. Plaque formation can be aggravated when luminal erosion or rupture occur leading to recruitment of circulating platelets (Koenig and Khuseyinova 2007). Interestingly, platelets have been shown not to be only implicated in thrombotic complications observed in advanced atherosclerotic lesions, but to also play crucial roles in early events of atherogenesis (Chapman 2007). Indeed, it has been demonstrated that the adhesion of platelets to the endothelium is an event that occurs before the appearance of atherosclerotic lesions (Davi and Patrono 2007). Adhered and activated platelets participate directly and indirectly in leukocyte recruitment and transmigration toward the endothelium barrier by the expression of adhesion molecules at their surface and the release of pro-inflammatory mediators which consequently interfere with the normal functions of endothelial cells (Lindemann et al. 2007). Furthermore, blockade of the adenosine 5'-diphosphate (ADP) $\mathrm{P}_{2} \mathrm{Y}_{12}$ receptor, with the antagonist clopidogrel or through its genetic deletion, reduces plaque progression and macrophage infiltration in the aortic arch of ApoE-/- atherosclerotic mice (Heim et al. 2016; Li et al. 2012). Studies have demonstrated that increased platelet reactivity in patients after percutaneous coronary intervention correlates with an increased risk of cardiovascular events (Gurbel et al. 2005). The key role of platelets has been highlighted by clinical trials over the last years showing that the use of platelet $\mathrm{P}_{2} \mathrm{Y}_{12}$ receptor antagonists, such as clopidogrel, prasugrel and ticagrelor, given with aspirin in patients with acute coronary syndrome, reduces the 
risk of subsequent events and of cardiovascular mortality. These drugs have become the standard of care in these patients (Tanguay et al. 2013). Taken together the evidence mentioned above highlight an important implication of platelets at different stages of atherosclerotic lesion progression.

In physiological conditions, the vascular endothelium limits platelet activation. Indeed, this cell monolayer, when stimulated by agonists, produces additional prostacyclin $\left(\mathrm{PGI}_{2}\right)$ which can inhibit platelet aggregation via cyclic adenosine 3'5'monophosphate (cAMP)dependent mechanisms (Geiger 2001). Both endothelin-1 (ET-1) and bradykinin (BK) inhibit platelet aggregation ex vivo in the mouse model (Labonté et al. 2001) and we have shown an increased plasma level of the $\mathrm{PGI}_{2}$ stable metabolite, 6-keto $\mathrm{PGF}_{1 \alpha}$, following intravenous administration of those two peptides in mice (Carrier et al. 2007).

Conversely, in atherosclerotic disease, the endothelium-dependent mechanisms become altered (Schafer and Bauersachs 2008). In particular, endothelial cell synthetic activities switch from the production of protective vasodilators and platelet inhibitory molecules observed in physiological conditions towards increased synthesis of free radicals and vasoconstrictor agents (Vanhoutte 1997). The endothelial dysfunction and increased platelet reactivity observed in atherosclerosis prompt the question as to whether endothelial-dependent inhibition of platelet aggregation is still effective in this pathological state. Therefore, the aim of the present study was to determine if the platelet inhibitory properties of $\mathrm{PGI}_{2}$-releasing peptides, such as ET-1 and $\mathrm{BK}$, are altered in an animal model of atherosclerosis, the ApoE-/- mouse. This mouse model spontaneously 
develops atherosclerosis under chow diet (Jawień et al. 2004; Nakashima et al. 1994) from early lesions characterized by monocyte adhesion (8-10 weeks old) to foam cell lesions (9-30 weeks old), then to intermediate lesions ( $>16$ weeks old) and finally to fibrous plaque (>21 weeks old) (Jawień et al. 2004). 


\section{Materials and methods}

Animals

Wild-type (WT) mice (males and females) C57BL/6J were purchased from Charles River (Montreal, QC, Canada). Breeding couples of homozygous ApoE-/- mice (Piedrahita et al. 1992), on the same genetic background, were initially obtained from Jackson Laboratory (Bar Harbor, ME, USA) and a colony subsequently developed in our facilities. The ApoE-/- genotype was confirmed by the polymerase chain reaction (PCR) method performed on DNA extracts. Mice used for the present study were all maintained on chow diet until the day of experiment (aged 8-10 or 18-20 weeks old).

All animals were kept at constant room temperature $\left( \pm 23^{\circ} \mathrm{C}\right)$ and humidity $(\sim 78 \%)$ under a controlled light-dark cycle (6H00 AM-6H00 PM).

Animal care and experimentations were approved by the Ethics Committee on Animal Research of the Universite de Sherbrooke, in accordance with the Guide to the Care and Use of Experimental Animals from the Canadian Council on Animal Care.

\section{Surgical procedures in anesthetized animals}

Mice were anesthetized with ketamine-xylazine (i.m.: $87 \mathrm{mg} \mathrm{kg}^{-1}-13 \mathrm{mg} \mathrm{kg}^{-1}$ ) and then, the jugular vein and carotid artery were cannulated for intravenous (i.v.) injection, blood pressure monitoring and blood sampling as previously reported (Carrier et al. 2007). 


\section{Inhibition of platelet aggregation ex vivo}

The determination of platelet responses ex vivo to i.v. injection of ET-1 (0.1 and $\left.1 \mathrm{nmol} \mathrm{kg}^{-1}\right)$, bradykinin $\left(2.5\right.$ and $\left.10 \mathrm{nmol} \mathrm{kg}^{-1}\right)$ or the vehicle (PBS) was performed in WT and ApoE-/- mice. Briefly, 5 minutes after the i.v. injection, blood pooled from 2 mice $(1.5 \mathrm{~mL})$ was collected using heparin $\left(15\right.$ units $\left.\mathrm{mL}^{-1}\right)$ as anticoagulant $(\mathrm{AC})$. In another series of experiments, $\mathrm{PGI}_{2}\left(1 \mu \mathrm{g} \mathrm{kg} \mathrm{min}^{-1}\right)$ was infused $\left(10 \mu \mathrm{L} \mathrm{min}{ }^{-1}\right)$ during 5 min, after which blood was immediately collected. Platelet rich (PRP) and poor (PPP) plasma were obtained by centrifugation of the whole blood sample. Adenosine 5'-diphosphate (ADP) was used to induce platelet aggregation in the PRP in order to obtain between $40 \%$ and $50 \%$ platelet aggregation in each control (PBS) experiment. Platelet aggregation was measured using an aggregometer model 490-2D (Chrono-Log Corporation, Havertown, PA, USA).

Inhibition of platelet aggregation in vitro using an aggregometer

Blood was collected from WT and ApoE-/- mice using sodium citrate $3.8 \%\left(\mathrm{w} \mathrm{v}^{-1}\right)$ as AC at a 9:1 ratio (2 mice: $1.5 \mathrm{~mL}$ of blood). Once the PRP and PPP had been obtained by centrifugation, platelet response to ADP in the PRP was monitored after addition of a nitric oxide (NO) donor, sodium nitroprusside (SNP, $40 \mu \mathrm{M}$ ); a stable prostacyclin analogue, iloprost (100 nM); or saline $0.9 \%$, as previously reported (Carrier et al. 2007). 


\section{Inhibition of platelet aggregation in vitro using a microplate reader}

Blood was pooled from two mice of the same strain and PRP and PPP were prepared as described above. The AC used depended on the aggregating agent used, i.e. heparin 15 units $\mathrm{mL}^{-1}$ for $\mathrm{U} 46619$, or sodium citrate $3.5 \%\left(\mathrm{w} \mathrm{v}^{-1}\right)$ at a ratio of 9:1 for ADP. The microplate reader and half-area Costar microplate (Corning Incorporated, Corning, NY, USA) were pre-heated at $37^{\circ} \mathrm{C}$. The PPP and PRP were simultaneously added to wells already containing either the vehicle (saline $0.9 \%$ ) or an aggregating agent (ADP or U46619: 1-50 $\mu \mathrm{M}$ ). The optical density was measured every 30 seconds over a 30 -minute period using a Spectra Max Plus 384 plate reader (Molecular Devices, Sunnyvale, CA, USA) at $560 \mathrm{~nm}$. Changes in the difference of optical density between PPP and PRP, with a correction from wells with PRP + vehicle, were converted to a percentage of platelet aggregation. This method was similar to the one described by Armstrong and colleagues (Armstrong et al. 2008). Data are expressed as percentage of maximum variation in light transmission from baseline measure using the following equation:

$\%$ platelet aggregation $=\left(\frac{(\Delta(P R P a-P P P a)-\Delta(P R P v-P P P v))_{\max }}{\Delta(P R P a-P P P a)_{0}}\right) \times 100$

$a$ is for aggregating agent, $v$ is for vehicle, 0 is the initial measurement.

\section{Plasma levels of Prostacyclin}

Formation of prostacyclin within the blood of WT and ApoE-/- mice was assessed by measuring its stable metabolite, 6-keto prostaglandin $\mathrm{F}_{1 \alpha}\left(6-\mathrm{keto}_{\mathrm{PGF}}\right.$ ). Briefly, blood samples were collected after i.v. injection of vehicle (PBS), ET-1 $\left(0.1 \mathrm{nmol} \mathrm{kg}^{-1}\right)$ or BK 
$\left(10 \mathrm{nmol} \mathrm{kg}{ }^{-1}\right)\left(\mathrm{AC}:\right.$ sodium citrate 3.5\% ( $\left.\mathrm{w} \mathrm{v}^{-1}\right)$, ratio 9:1). Plasma samples were obtained by centrifugation and frozen at $-80{ }^{\circ} \mathrm{C}$. The 6-keto $\mathrm{PGF}_{1 \alpha}$ plasma concentration was then quantified using an enzyme immunoassay (EIA) kit (Cayman Chemical, Ann Harbor, MI, USA).

Platelet levels of cyclic adenosine 3',5' monophosphate (cAMP)

Blood samples of $800 \mu \mathrm{L}$ (AC: sodium citrate $3.5 \%\left(\mathrm{w} \mathrm{v}^{-1}\right)$ ratio 9:1) were collected 30 seconds after i.v. injection of vehicle (PBS), BK $\left(10 \mathrm{nmol} \mathrm{kg}{ }^{-1}\right)$ or iloprost $\left(10 \mu \mathrm{g} \mathrm{kg}^{-1}\right)$. In another series of experiments, $\mathrm{PGI}_{2}\left(1 \mu \mathrm{g} \mathrm{kg} \mathrm{min}^{-1}\right)$ was infused $\left(10 \mu \mathrm{min}^{-1}\right)$ during 5 min, after which blood was immediately collected. PRP at a volume of $200 \mu \mathrm{L}$ was then obtained after a centrifugation of blood samples for 12 minutes at $120 \mathrm{~g}$. Thereafter, the PRP was centrifuged at $1500 \mathrm{~g}$ for 10 minutes to isolate the platelets which were then re-suspended in $100 \mu \mathrm{L} 0.1 \mathrm{M} \mathrm{HCl}$ and incubated gently on a shaker for 20 minutes to allow platelet lysis. A further centrifugation at $1000 \mathrm{~g}$ for 10 minutes was performed, the supernatant was collected and then snap frozen at $-80^{\circ} \mathrm{C}$ until the assay. The assay was performed using a cAMP EIA Kit from Cayman Chemical according to the manufacturer's recommendations, using the acetylation protocol for enhanced sensitivity.

\section{En face analysis of aorta atherosclerotic lesions}

Aortas were collected in one piece from the aortic root until the iliac bifurcation. Vessels were cleaned carefully, opened longitudinally and pinned on a black silicone surface. 
Aortas were then fixed overnight in a solution of paraformaldehyde $4 \%$ in which $5 \%$ sucrose was freshly added. The following morning, the paraformaldehyde + sucrose solution was removed and replaced by ethanol $70 \%$ for a 30 -second tissue wash. The aortas were then stained for 30 minutes with an oil red-O solution $0.5 \% \mathrm{w} \mathrm{v}^{-1}$ prepared in acetone:ethanol:water $(50: 35: 15)$. Thereafter, the vessels were washed with ethanol $80 \%$ for 10 minutes. Finally, aortas were placed in PBS and photographed with a NikonD1X (AF MICRO NIKKOR/60mm/1:2.8 D). Surface analysis was performed using an AxioVision 4.6.3 program (Carl Zeiss, Toronto, ON, Canada).

\section{Chemicals}

ADP was obtained from Chrono-Log Corporation or Sigma (Oakville, ON, Canada) and reconstituted in sterile irrigation grade saline $0.9 \%\left(\mathrm{w} \mathrm{v}^{-1}\right)$. The methyl acetate solvent for U46619 (Cayman Chemical) was evaporated with a gentle stream of argon and U46619 was dissolved in saline $0.9 \%$ by sonication for 3 minutes right before the experiment. The iloprost (Cayman Chemical) solution was prepared as the U46619 solution, but without the sonication procedure. The $\mathrm{PGI}_{2}$ sodium salt (Cayman Chemical) was dissolved and aliquoted in ethanol and stored at $-20{ }^{\circ} \mathrm{C}$. On the day of the experiment, one aliquot was evaporated with argon and re-dissolved in a PBS at pH 9.0. ET-1 (Peptides International, Louisville, KY, USA) and BK (American Peptide, Sunnyvale, CA, USA) were reconstituted and diluted with PBS (pH 7.4).

\section{Statistical analysis}


Data were expressed as mean \pm SEM of $n$ experiments. Statistical analyses were performed by one-way ANOVA with Bonferroni's post-test for selected comparisons. * or $\# P<0.05, * *$ or $\# \# P<0.01$. 


\section{Results}

Basal blood parameters in WT and ApoE-/- mice

A significant decrease in the hematocrit was observed in ApoE-/- mice when compared to WT mice at 8-10 weeks of age (WT: $43.9 \pm 0.5$; ApoE-/-: $40.2 \pm 0.9 \%, P<0.01 ; n=6-8$ for each type of mice) and at 18-20 weeks of age (WT: $44.6 \pm 0.2$; ApoE-/-: $41.1 \pm 0.7 \%$, $P<0.01 ; n=11$ for each type of mice). No significant differences were however found between ApoE-/- and WT mice in terms of blood platelet counts (WT: 1,068.6 \pm 78.1; ApoE-/-: $1,323.1 \pm 100.0 \times 10^{3}$ platelets $\mu \mathrm{L}^{-1} ; n=6-8$ for each mouse strain).

Concentration-dependent platelet aggregation in vitro in response to U46619 and ADP in WT and ApoE-/- mice

The effect of age (8-10 weeks or 18-20 weeks of age) on basal platelet reactivity were investigated in ApoE-/- and WT mice using different concentrations of ADP and U46619, a thromboxane $\mathrm{A}_{2}\left(\mathrm{Tx}_{2}\right)$ mimetic. Figure 1 shows that platelet aggregation in response to both agonists did not differ between the two age groups in WT mice (Fig. 1A and 1C). In contrast, in ApoE-/- mice, significant increases in platelet aggregation induced by ADP (Fig. 1B) and U46619 (Fig. 1D) were observed at 18-20 weeks of age compared to 8-10 weeks of age. 
Endothelin-1 and bradykinin-induced inhibition of platelet aggregation ex vivo in WT and ApoE-/- mice

ET-1 $\left(0.1 \mathrm{nmol} \mathrm{kg}^{-1}\right)$ and BK $\left.(10 \mathrm{nmol} \mathrm{kg})^{-1}\right)$ inhibited ADP-induced platelet aggregation ex vivo in a similar fashion in 8-10 week-old WT and ApoE-/- mice (Fig. 2B). ET-1 (0.1 and $1.0 \mathrm{nmol} \mathrm{kg}-1)$ and $\mathrm{BK}\left(2.5\right.$ and $\left.10 \mathrm{nmol} \mathrm{kg}^{-1}\right)$ were also both shown to reduce platelet aggregation $(P<0.01)$ in $18-20$ week-old WT mice, although their anti-platelet effect was statistically significantly reduced in 18-20 week-old ApoE-/- mice (Fig. 3B). The corresponding pressor responses to ET-1 and BK were not altered in ApoE-/- mice compared to WT animals (Figs. 2A and 3A).

En face analysis of atherosclerotic lesions in the aorta of WT and ApoE-/- mice

Total aortic surface area did not differ between WT and ApoE-/- mice at either 8-10 weeks or 18-20 weeks of age (data not shown). Representative examples of stained aortas of 18-20 week-old WT and ApoE-/- mice are shown in Fig 4A where lesions are delimited by yellow lines. The percentage of the total aortic area covered by lesions was found to be greater in ApoE-/- mice than in WT mice at both ages (Fig. 4B). No differences were however observed between the younger and older ApoE-/- mice in terms of surface covered by lesions (Fig. 4B). The lesion number and average size also did not differ between age groups (data not shown). 
BK and ET-1 -dependent release of prostacyclin in WT and ApoE-/- (18-20 weeks old) mice

We have previously reported that $\mathrm{BK}$ is more potent in stimulating the release of $\mathrm{PGI}_{2}$ than ET-1 in the plasma of WT mice (Carrier et al. 2007). Basal plasma levels of 6-keto PGF $_{1 \alpha}$ were shown not to differ between ApoE-/- and WT mice (Fig. 5A). Similarly, i.v. administration of BK (10 nmol kg-1) (Fig. 5B) or ET-1 (0.1 nmol kg-1) (Fig. 5A) increased plasma levels of 6-keto $\mathrm{PGF}_{1 \alpha}$ to the same extent in WT and ApoE -/- mice at 18-20 weeks of age.

Inhibition of platelet aggregation by iloprost, SNP or PGI $I_{2}$ in WT and ApoE-/- mice

In order to determine whether the loss of the anti-platelet properties of ET-1 and BK observed in the 18-20 week-old ApoE-/- mice (Fig. 3B) could be explained by a decreased responsiveness of their platelets to inhibitory factors, the anti-platelet effects of a $\mathrm{PGI}_{2}$ analogue (iloprost) and a nitric oxide donor (SNP) were investigated. Iloprost $(100 \mathrm{nM})$ and SNP $(40 \mu \mathrm{M})$ were shown to similarly inhibit platelet aggregation in vitro in WT and ApoE-/- mice when directly administered in the PRP (Fig. 5C). Nonetheless, prostacyclin i.v. infusion failed to inhibit platelet aggregation ex vivo in the 18-20 weekold ApoE-/- mice (Fig. 5D), similarly to the observations previously made for ET-1 and BK (Fig 3B). No differences in terms of the blood pressure lowering effect of the $\mathrm{PGI}_{2}$ i.v. infusion were observed (Fig. 5E). 
$B K$, iloprost or $\mathrm{PGI}_{2}$-dependent increase of platelet cAMP in WT and ApoE-/- mice

The cAMP concentration in platelets from WT and ApoE-/- mice (8-10 weeks old and 18-20 weeks old) was measured following i.v. administration of PBS or BK $\left(10 \mathrm{nmol} \mathrm{kg}^{-1}\right)$. In addition, cAMP production was monitored in platelets derived from WT or ApoE-/- 18-20 week-old mice systemically administered with iloprost (bolus: $10 \mu \mathrm{g} \mathrm{kg}^{-1}$ ) or $\mathrm{PGI}_{2}$ (infusion: $1 \mu \mathrm{g} \mathrm{kg}^{-1} \min ^{-1} ; 10 \mu \mathrm{l} \mathrm{min}{ }^{-1} ; 5 \mathrm{~min}$ ). Basal levels of platelet cAMP did not differ by age or genotype groups (Fig. 6). Interestingly, BK induced a statistically significant increase in platelet cAMP in all mice, including 18-20 week-old ApoE-/- animals (Fig. 6). Furthermore, iloprost and $\mathrm{PGI}_{2}$ increased intraplatelet cAMP levels in 18-20 week-old ApoE-/- and WT mice (Fig. 6). 


\section{Discussion}

The principal conclusions drawn from the present study is that mice with intermediate atherosclerotic lesions are less responsive than their WT congeners to the platelet inhibitory effects of ET-1 and BK. Interestingly, intravenous administration of BK and $\mathrm{PGI}_{2}$ did not inhibit platelet aggregation ex vivo in 18-20 week-old ApoE-/- mice despite their capacity to increase intra-platelet levels of cAMP. We also show that the alteration of the platelet inhibitory capacities of ET-1 and BK in ApoE-/- mice progresses with age, which is consistent with the observation of a progressive increase in the response to proaggregating agents (ADP and U46619).

Several groups demonstrated a correlation between atherosclerosis and enhanced platelet reactivity in human (Aoki et al. 2006; Bliden et al. 2007; Gurbel et al. 2005; Rajagopalan et al. 2007) as well as in ApoE-/- mice (Eitzman et al. 2000). Numerous mechanisms have been associated with this enhanced responsiveness, such as enhanced COX-1-derived TxA 2 synthesis (Pfister 2006), increased production of oxidants (Maytin et al. 1999) and loss of functional integrity of the vascular endothelium (Russo et al. 2002). To our knowledge, however, the present study reports a novel concept of loss of anti-platelet mechanisms within the intermediate, but not early, atherosclerotic processes. Indeed, the inhibitory properties of both ET-1 and BK are left intact in 8-10 week-old mice yet markedly reduced in older ApoE-/- mice aged from 18-20 weeks. This alteration of the anti-platelet properties of both ET-1 and BK suggests that the phenomenon would probably not be associated with a decrease in specific receptor activation-derived signal 
transduction. In support of this concept, no variations in mean arterial pressure (MAP) were observed following the injection of either agonist, at different doses, in ApoE-/mice when compared to WT animals.

Interestingly, we found that both $\mathrm{BK}$ and ET-1 increase $\mathrm{PGI}_{2}$ plasma levels in 18-20 week-old WT and ApoE-/- mice suggesting that the agonist-stimulated $\mathrm{PGI}_{2}$ production is left intact in the latter mouse strain. The $\mathrm{PGI}_{2} \mathrm{IP}$ receptor-dependent platelet inhibitory activity involves activation of adenylyl cyclase and subsequent increase in intra-platelet cAMP (Walter et al. 1993). In the present study, we show that BK and $\mathrm{PGI}_{2}$, when administered systemically, are able to trigger a statistically significant increase in platelet cAMP levels in ApoE-/- of both age groups. Intravenous administration of ET-1 may also increase intra-platelet cAMP in CD-1 control mice (Houde, personal communication), although we did not measure this effect in the present study. Hence, even though $\mathrm{PGI}_{2}$ is produced and released efficiently in the circulation of older ApoE-/- mice and platelet cAMP levels are increased following BK administration, it remains that BK loses its capacity to inhibit platelet aggregation in these mice. Furthermore, the highest dose of ET-1 $\left(1 \mathrm{nmol} \mathrm{kg}{ }^{-1}\right)$, itself a potent cAMP inducer in mouse platelets through $\mathrm{PGI}_{2}$ release (data not shown), exhibited some platelet inhibitory activity, while BK did not, even though $\mathrm{PGI}_{2}$ synthesis is much more robust for the latter peptide. These results suggest that the mechanism is not related to the binding of $\mathrm{PGI}_{2}$ to its IP receptor.

The ApoE-/- mice platelet sensitivity to direct aggregation inhibitors has also been investigated in the present study using a stable $\mathrm{PGI}_{2}$ analogue, iloprost (Ubatuba et al. 
1979). When incubated with platelets in vitro, iloprost inhibited platelet aggregation significantly in both WT and ApoE-/- mice aged 18-20 weeks. Another study, using washed platelets from 12-week old ApoE-/- mice on a 7-week atherogenic diet, reported a loss of the inhibitory actions of the NO donor glyceryl trinitrate (GTN), but not for the superoxide-insensitive HNO donor isopropylamine NONOate (Bullen et al. 2011). As BK may also inhibit platelet aggregation ex vivo through NO release (Labonté et al. 2001), we also showed that an NO donor, SNP, could inhibit platelet aggregation in vitro in 18-20 week old ApoE-/- mice on a normal diet. These results contrast with our ex vivo results, and suggest that inhibitory mechanisms in platelets are responsive to high concentrations of inhibitory molecules at this stage of the atherosclerotic development. Thus, the platelet inhibitory activities ex vivo of ET-1 and BK may be competing with short-lived pro-aggregation factors present in plasma. Supporting the role of plasma labile eicosanoids such as $\mathrm{TxA}_{2}$, Buga and colleagues found that differences in the platelet inhibitory properties of an ApoA1 peptide mimetic, L-4F, were found between 812 month-old WT and ApoE-/- mice in platelet rich plasma but not with washed platelets (Buga et al. 2010).

Our results show that in ApoE-/- mice, platelet sensitivity increased with age to both ADP and U46619. The most potent platelet aggregation in our study was observed with the endoperoxide analogue U46619 in 18-20 week-old ApoE-/- mice. TxA $\mathrm{A}_{2}$ synthesis is significantly increased in ApoE-/- mice between 8 and 20 weeks (Praticò et al. 2000). The $\mathrm{TxA}_{2} \mathrm{TP}$ receptor, which plays a role in the promotion of the atherosclerotic process (Cayatte et al. 2000; Kobayashi et al. 2004), may be activated by a wide variety of 
eicosanoids, including high-concentration $\mathrm{PGI}_{2}$, but not iloprost (Corriu et al. 2001; Vanhoutte et al. 2017). In contrast to $\mathrm{PGI}_{2}$, iloprost also activates the prostaglandin $\mathrm{E}_{2}$ receptor 4 (EP4) which is also known to inhibit platelet function, hence providing another mechanism by which iloprost may inhibit platelets (Breyer et al. 2001). Our results suggest that the TP receptor aggregation pathway may be more sensitive as the atherosclerotic lesions develop into the intermediate stages in ApoE-/- mice. It may thus contribute to the increased ADP and U46619 -induced platelet aggregation observed. It could also contribute to a double action of $\mathrm{PGI}_{2}$ in these animals, as $\mathrm{PGI}_{2}$ could activate an over-sensitive TP receptor to counteract the cAMP and cGMP mediated platelet inhibition by BK (Carrier et al. 2007; Labonté et al. 2001; Vanhoutte et al. 2017).

Vascular lesions develop spontaneously in ApoE-/- mice and this pathological process can be accelerated by feeding the animals with a Western high-fat diet. The data presented in this study, with ApoE-/- mice under normal diet, illustrates that internal surface covered by lesions in the entire aorta does not progress macroscopically between ages of 8-10 and 18-20 weeks in these mice. In support of this concept, Jawien and coworkers have shown that the aortic sinus lesions progress only slightly between 10 and 20 weeks of age in ApoE-/- mice (Jawień et al. 2004). It is also of interest that disease in ApoE-/- mice of 18-20 weeks old is characterized by foam cells and intermediate lesions (Nakashima et al. 1994). Thus, alterations in the reactivity of circulating platelets to TP agonists could take place in the relatively early stages of atherosclerosis progression, before the development of advanced lesions. If our results are to be transposed to humans, our interpretation would suggest that the loss of this protective anti-platelet 
mechanism occurs before the observation of clinical signs associated with advanced atherosclerotic lesions. For instance, young smokers (25 years old) show a decrease of phosphorylated vasodilator stimulated phosphoprotein (VASP-P) levels, a central inhibitory mechanism in platelets, both at an endogenous level and after prostaglandin $\mathrm{E}_{1}$ incubation, suggesting an early effect of this atherosclerosis risk factor (Assinger et al. 2010). Thus, the analysis of platelet reactivity to endogenous inhibitory factors could be used as an early marker of the vascular degeneration involved in atherosclerosis.

Inhibitors of the hydroxy-methyl-glutaryl coenzyme A (HMG-CoA) reductase (the statin class), such as atorvastatin and simvastatin, can modulate platelet activation and thrombus formation in mice, although their effects on ex vivo platelet aggregation remains unclear (Moraes et al. 2013; Ni et al. 2012; Owens et al. 2012; Schafer et al. 2005). As statins can also slow atherosclerotic disease progression (Johnson et al. 2005; Scalia et al. 2001), the effect of these inhibitors on the endothelium-dependent platelet inhibition in ApoE-/- mice needs to be established.

In summary, our results highlight a reduced effectiveness of inhibitory mechanisms in circulating platelets in a mouse model of atherosclerosis. This takes place before the occurrence of advanced atherosclerotic lesions. Therefore, the present study sheds new light on the mechanisms involved in the increased platelet reactivity associated to this pathological state. 


\section{Acknowledgements}

We gratefully acknowledge Mrs. Helen Morin for secretarial assistance and Mr. Robert Dumont (Service des technologies de l'information et des communications, Université de Sherbrooke) for the photographic material used for en face analysis of vascular lesions. This project is financially supported by the Canadian Institutes for Health Research. P.D.J. is a JC Edwards Cardiovascular Chair. 


\section{References}

Aoki, R., Ikarugi, H., Naemura, A., Ijiri, Y., Yamashita, T. and Yamamoto, J. 2006. Endothelial dysfunction precedes atherosclerotic lesions and platelet activation in high fat diet-induced prothrombotic state. Thromb. Res. 117(5): 529-35. doi:10.1016/j.thromres.2005.04.022. PMID:15916796

Armstrong, P. C., Truss, N. J., Ali, F. Y., Dhanji, A. A., Vojnovic, I., Zain, Z. N., BishopBailey, D., Paul-Clark, M. J., Tucker, A. T., Mitchell, J. A. and Warner, T. D. 2008. Aspirin and the in vitro linear relationship between thromboxane A2mediated platelet aggregation and platelet production of thromboxane A2. J. Thromb. Haemost. 6(11): 1933-43. doi:10.1111/j.1538-7836.2008.03133.x. PMID: 18752570

Assinger, A., Schmid, W. and Volf, I. 2010. Decreased VASP phosphorylation in platelets of male and female smokers of young age. Platelets. 21(8): 596-603. doi:10.3109/09537104.2010.505674. PMID:20822337

Bliden, K. P., DiChiara, J., Tantry, U. S., Bassi, A. K., Chaganti, S. K. and Gurbel, P. A. 2007. Increased risk in patients with high platelet aggregation receiving chronic clopidogrel therapy undergoing percutaneous coronary intervention: is the current antiplatelet therapy adequate? J. Am. Coll. Cardiol. 49(6): 657-66. doi:10.1016/j.jacc.2006.10.050. PMID:17291930

Breyer, R. M., Bagdassarian, C. K., Myers, S. A. and Breyer, M. D. 2001. Prostanoid receptors: subtypes and signaling. Annu. Rev. Pharmacol. Toxicol. 41(661-90. PMID:11264472

Buga, G. M., Navab, M., Imaizumi, S., Reddy, S. T., Yekta, B., Hough, G., Chanslor, S., Anantharamaiah, G. M. and Fogelman, A. M. 2010. L-4F alters hyperlipidemic (but not healthy) mouse plasma to reduce platelet aggregation. Arterioscler. Thromb. Vasc. Biol. 30(2): 283-9. doi:10.1161/ATVBAHA.109.200162. PMID:19965777

Bullen, M. L., Miller, A. A., Dharmarajah, J., Drummond, G. R., Sobey, C. G. and Kemp-Harper, B. K. 2011. Vasorelaxant and antiaggregatory actions of the nitroxyl donor isopropylamine NONOate are maintained in hypercholesterolemia. Am. J. Physiol. Heart Circ. Physiol. 301(4): H1405-14. doi:10.1152/ajpheart.00489.2011. PMID:21803947

Carrier, E., Brochu, I., de Brum-Fernandes, A. J. and D'Orléans-Juste, P. 2007. The inducible nitric-oxide synthase modulates endothelin-1-dependent release of prostacyclin and inhibition of platelet aggregation ex vivo in the mouse. J. Pharmacol. Exp. Ther. 323(3): 972-8. doi:10.1124/jpet.107.125690. PMID:17885093

Cayatte, A. J., Du, Y., Oliver-Krasinski, J., Lavielle, G., Verbeuren, T. J. and Cohen, R. A. 2000. The thromboxane receptor antagonist S18886 but not aspirin inhibits atherogenesis in apo E-deficient mice: evidence that eicosanoids other than thromboxane contribute to atherosclerosis. Arterioscler. Thromb. Vasc. Biol. 20(7): 1724-8. PMID:10894809 
Chapman, M. J. 2007. From pathophysiology to targeted therapy for atherothrombosis: a role for the combination of statin and aspirin in secondary prevention. Pharmacol. Ther. 113(1): 184-96. doi:10.1016/j.pharmthera.2006.08.005. PMID:17070923

Corriu, C., Feletou, M., Edwards, G., Weston, A. H. and Vanhoutte, P. M. 2001. Differential effects of prostacyclin and iloprost in the isolated carotid artery of the guinea-pig. Eur. J. Pharmacol. 426(1-2): 89-94. PMID:11525776

Davi, G. and Patrono, C. 2007. Platelet activation and atherothrombosis. N. Engl. J. Med. 357(24): 2482-94. doi:10.1056/NEJMra071014. PMID:18077812

Eitzman, D. T., Westrick, R. J., Xu, Z., Tyson, J. and Ginsburg, D. 2000. Hyperlipidemia promotes thrombosis after injury to atherosclerotic vessels in apolipoprotein Edeficient mice. Arterioscler. Thromb. Vasc. Biol. 20(7): 1831-4. PMID:10894825

Geiger, J. 2001. Inhibitors of platelet signal transduction as anti-aggregatory drugs. Expert Opin Investig Drugs. 10(5): 865-90. doi:10.1517/13543784.10.5.865. PMID: 11322863

Gurbel, P. A., Bliden, K. P., Guyer, K., Cho, P. W., Zaman, K. A., Kreutz, R. P., Bassi, A. K. and Tantry, U. S. 2005. Platelet reactivity in patients and recurrent events post-stenting: results of the PREPARE POST-STENTING Study. J. Am. Coll. Cardiol. 46(10): 1820-6. doi:10.1016/j.jacc.2005.07.041. PMID:16286165

Heim, C., Gebhardt, J., Ramsperger-Gleixner, M., Jacobi, J., Weyand, M. and Ensminger, S. M. 2016. Clopidogrel significantly lowers the development of atherosclerosis in ApoE-deficient mice in vivo. Heart Vessels. 31(5): 783-94. doi:10.1007/s00380-015-0696-7. PMID:26062773

Jawień, J., Nastałek, P. and Korbut, R. 2004. Mouse models of experimental atherosclerosis. J Physiol Pharmacol. 55(3): 503-17. PMID:15381823

Johnson, J., Carson, K., Williams, H., Karanam, S., Newby, A., Angelini, G., George, S. and Jackson, C. 2005. Plaque rupture after short periods of fat feeding in the apolipoprotein E-knockout mouse: model characterization and effects of $\begin{array}{llll}\text { pravastatin treatment. } & \text { Circulation. } & \text { 111(11): }\end{array}$ doi:10.1161/01.CIR.0000158435.98035.8D. PMID:15781753

Kobayashi, T., Tahara, Y., Matsumoto, M., Iguchi, M., Sano, H., Murayama, T., Arai, H., Oida, H., Yurugi-Kobayashi, T., Yamashita, J. K., Katagiri, H., Majima, M., Yokode, M., Kita, T. and Narumiya, S. 2004. Roles of thromboxane A(2) and prostacyclin in the development of atherosclerosis in apoE-deficient mice. J. Clin. Invest. 114(6): 784-94. PMID:15372102

Koenig, W. and Khuseyinova, N. 2007. Biomarkers of atherosclerotic plaque instability and rupture. Arterioscler. Thromb. Vasc. Biol. 27(1): 15-26.

Labonté, J., Brochu, I., Honoré, J. C. and D'Orléans-Juste, P. 2001. Role of ETB and B2 receptors in the ex vivo platelet inhibitory properties of endothelin and bradykinin in the mouse. Br. J. Pharmacol. 132(4): 934-40.

Li, D., Wang, Y., Zhang, L., Luo, X., Li, J., Chen, X., Niu, H., Wang, K., Sun, Y., Wang, X., Yan, Y., Chai, W., Gartner, T. K. and Liu, J. 2012. Roles of purinergic receptor P2Y, G protein-coupled 12 in the development of atherosclerosis in apolipoprotein E-deficient mice. Arterioscler. Thromb. Vasc. Biol. 32(8): e81-9. doi:10.1161/ATVBAHA.111.239095. PMID:22628428

Lindemann, S., Kramer, B., Seizer, P. and Gawaz, M. 2007. Platelets, inflammation and atherosclerosis. J. Thromb. Haemost. 5 Suppl 1(203-11. PMID:17635728 
Maytin, M., Leopold, J. and Loscalzo, J. 1999. Oxidant stress in the vasculature. Curr Atheroscler Rep. 1(2): 156-64. PMID:11122705

Moraes, L. A., Vaiyapuri, S., Sasikumar, P., Ali, M. S., Kriek, N., Sage, T. and Gibbins, J. M. 2013. Antithrombotic actions of statins involve PECAM-1 signaling. Blood. 122(18): 3188-96. doi:10.1182/blood-2013-04-491845. PMID:24030383

Nakashima, Y., Plump, A. S., Raines, E. W., Breslow, J. L. and Ross, R. 1994. ApoEdeficient mice develop lesions of all phases of atherosclerosis throughout the arterial tree. Arterioscler. Thromb. 14(1): 133-40.

Ni, R., Peleg, T. and Gross, P. L. 2012. Atorvastatin delays murine platelet activation in vivo even in the absence of endothelial NO synthase. Arterioscler. Thromb. Vasc. Biol. 32(11): 2609-15. doi:10.1161/ATVBAHA.112.300090. PMID:22995523

Owens, A. P., 3rd, Passam, F. H., Antoniak, S., Marshall, S. M., McDaniel, A. L., Rudel, L., Williams, J. C., Hubbard, B. K., Dutton, J. A., Wang, J., Tobias, P. S., Curtiss, L. K., Daugherty, A., Kirchhofer, D., Luyendyk, J. P., Moriarty, P. M., Nagarajan, S., Furie, B. C., Furie, B., Johns, D. G., Temel, R. E. and Mackman, N. 2012. Monocyte tissue factor-dependent activation of coagulation in hypercholesterolemic mice and monkeys is inhibited by simvastatin. J. Clin. Invest. 122(2): 558-68. doi:10.1172/JCI58969. PMID:22214850

Pfister, S. L. 2006. Aortic thromboxane receptor deficiency alters vascular reactivity in cholesterol-fed rabbits. $\quad$ Atherosclerosis. 189(2): 358-63. doi:10.1016/j.atherosclerosis.2006.02.004. PMID:16515789

Piedrahita, J. A., Zhang, S. H., Hagaman, J. R., Oliver, P. M. and Maeda, N. 1992. Generation of mice carrying a mutant apolipoprotein $\mathrm{E}$ gene inactivated by gene targeting in embryonic stem cells. Proc. Natl. Acad. Sci. U. S. A. 89(10): 4471-5. PMID: 1584779

Praticò, D., Cyrus, T., Li, H. and FitzGerald, G. A. 2000. Endogenous biosynthesis of thromboxane and prostacyclin in 2 distinct murine models of atherosclerosis. Blood. 96(12): 3823-6. PMID:11090066

Rajagopalan, S., McKay, I., Ford, I., Bachoo, P., Greaves, M. and Brittenden, J. 2007. Platelet activation increases with the severity of peripheral arterial disease: implications for clinical management. J. Vasc. Surg. 46(3): 485-90. doi:10.1016/j.jvs.2007.05.039. PMID:17826235

Russo, G., Leopold, J. A. and Loscalzo, J. 2002. Vasoactive substances: nitric oxide and endothelial dysfunction in atherosclerosis. Vascul. Pharmacol. 38(5): 259-69. PMID: 12487030

Scalia, R., Gooszen, M. E., Jones, S. P., Hoffmeyer, M., Rimmer, D. M., 3rd, Trocha, S. D., Huang, P. L., Smith, M. B., Lefer, A. M. and Lefer, D. J. 2001. Simvastatin exerts both anti-inflammatory and cardioprotective effects in apolipoprotein Edeficient mice. Circulation. 103(21): 2598-603. PMID:11382730

Schafer, A. and Bauersachs, J. 2008. Endothelial dysfunction, impaired endogenous platelet inhibition and platelet activation in diabetes and atherosclerosis. Curr. Vasc. Pharmacol. 6(1): 52-60. PMID:18220940

Schafer, A., Fraccarollo, D., Eigenthaler, M., Tas, P., Firnschild, A., Frantz, S., Ertl, G. and Bauersachs, J. 2005. Rosuvastatin reduces platelet activation in heart failure: role of NO bioavailability. Arterioscler. Thromb. Vasc. Biol. 25(5): 1071-7. doi:10.1161/01.ATV.0000161926.43967.df. PMID:15761193 
Tanguay, J. F., Bell, A. D., Ackman, M. L., Bauer, R. D., Cartier, R., Chan, W. S., Douketis, J., Roussin, A., Schnell, G., Verma, S., Wong, G., Mehta, S. R. and Canadian Cardiovascular, S. 2013. Focused 2012 update of the Canadian Cardiovascular Society guidelines for the use of antiplatelet therapy. Can. J. Cardiol. 29(11): 1334-45. doi:10.1016/j.cjca.2013.07.001. PMID:23978596

Ubatuba, F. B., Moncada, S. and Vane, J. R. 1979. The effect of prostacyclin (PGT2) on platelet behaviour. Thrombus formation in vivo and bleeding time. Thromb. Haemost. 41(2): 425-35. PMID:382434

Vanhoutte, P. M. 1997. Endothelial dysfunction and atherosclerosis. Eur. Heart J. 18 Suppl E(E19-29. PMID:9402468

Vanhoutte, P. M., Shimokawa, H., Feletou, M. and Tang, E. H. 2017. Endothelial dysfunction and vascular disease - a 30th anniversary update. Acta Physiol (Oxf). 219(1): 22-96. doi:10.1111/apha.12646. PMID:26706498

Walter, U., Eigenthaler, M., Geiger, J. and Reinhard, M. 1993. Role of cyclic nucleotidedependent protein kinases and their common substrate VASP in the regulation of human platelets. Adv Exp Med Biol. 344(237-49. PMID:8209791 


\section{Legends for figures}

Fig. 1. In vitro platelet aggregation analyzed in a microplate reader following addition of increasing concentrations of $\operatorname{ADP}(\mathrm{A}, \mathrm{B})$ or $\mathrm{U} 46619$ (a TxA $\mathrm{A}_{2}$ mimetic) $(\mathrm{C}, \mathrm{D})$ in platelet rich plasma (PRP) of WT and ApoE-/- mice of 8-10 or 18-20 weeks of age. Results are expressed in percentage $(\%)$ of platelet aggregation **: $P<0.01 ; *: P<0.05$ vs mice of 8-10 weeks of age. $n=4-8$.

Fig. 2. Effects of the intravenous administration of vehicle (PBS), ET-1 $\left(0.1 \mathrm{nmol} \mathrm{kg}^{-1}\right)$ or BK (10 $\left.\mathrm{nmol} \mathrm{kg}^{-1}\right)$ on mean arterial pressure (AMAP) (A) platelet aggregation ex vivo (B) in WT and ApoE-/- mice aged 8-10 weeks. Results are expressed in percentage (\%) of platelet aggregation. **: $P<0.01 ; *: P<0.05 v s$ vehicle (PBS) treatment. $n=5-6$.

Fig. 3. (A) Maximum variation $(\Delta)$ of MAP $(\mathrm{mmHg})$ of PBS, ET-1, and BK in in WT and ApoE-/- mice aged 18-20 weeks. (B) Effects of the intravenous administration of vehicle (PBS) and two different doses of ET-1 $\left(0.1\right.$ or $\left.1 \mathrm{nmol} \mathrm{kg}^{-1}\right)$ or BK $\left(2.5\right.$ or $\left.10 \mathrm{nmol} \mathrm{kg}^{-1}\right)$ on platelet aggregation ex vivo these same strains of mice. Results are expressed in percentage (\%) of platelet aggregation. $n=5-8$. \#\#: $P<0.01$; \#: $P<0.05$ vs the same dose in WT mice. $n=10-16 . * *: P<0.01 ; *: P<0.05$ vs PBS in the same group of mice 
Fig. 4. En face analysis of the surface covered by lesions in aorta of WT and ApoE-/mice aged from $8-10$ or $18-20$ weeks using oil red-O staining. Representative aortas from 18-20 week old mice are shown in A, with the lipidic areas delimited with yellow. Results of the analysis are expressed as percentage (\%) of the total area covered by lesions, in the whole aorta and specifically in the $\operatorname{arch}(\mathrm{B}) *: P<0.05 v s$ WT mice. $n=6$.

Fig. 5. Plasma concentrations $\left(\mathrm{pg} \mathrm{mL}^{-1}\right)$ of 6-keto $\mathrm{PGF}_{1 \alpha}$ following the intravenous administration of vehicle (PBS), BK (10 nmol kg-1) (A) or ET-1 $\left(0.1 \mathrm{nmol} \mathrm{kg}^{-1}\right)(\mathrm{B})$ in WT and ApoE-/- mice (18-20 weeks old). $n=5-8$. (C) Inhibition of ADP-induced platelet aggregation in vitro, obtained following addition of iloprost (ILO: $100 \mathrm{nM}$ ), a prostacyclin analogue, or sodium nitroprusside (SNP: $40 \mu \mathrm{M})$ in the PRP of WT and ApoE-/- mice (18-20 weeks old). The control aggregation has been fixed to $100 \%$ and the results are then expressed as relative to control. $\left(n=6-7 .{ }^{*}: P<0.01 ; *: P<0.05\right.$ vs control (CTL). (D) ADP-induced platelet aggregation ex vivo in 18-20 week old WT and ApoE-/- mice following $\mathrm{PGI}_{2}$ infusion $\left(1 \mu \mathrm{g} \mathrm{kg}^{-1} \mathrm{~min}^{-1}, 10 \mu \mathrm{min}^{-1}\right)$ or its vehicle (PBS $\mathrm{pH}$ 9.0). Results are expressed as percentage (\%) of platelet aggregation. $\mathrm{n}=5-7, * *: \mathrm{P}<$ 0.01 vs. PBS; *: $\mathrm{P}<0.05$ vs PBS. (E) The average MAP profile of $\mathrm{PGI}_{2}$ infused intravenously ( $\left.1 \mu \mathrm{g} \mathrm{kg}^{-1} \mathrm{~min}^{-1}, 10 \mu \mathrm{min}^{-1}, 5 \mathrm{~min}\right)$ in WT and ApoE-/- mice (8-10 and 18-20 weeks old). $n=10-12$.

Fig. 6. Intra-platelet cAMP concentrations following intravenous administration of vehicle (PBS), bradykinin (BK: $10 \mathrm{nmol} \mathrm{kg}^{-1}$ ), iloprost (ILO: $10 \mu \mathrm{g} \mathrm{kg}^{-1}$ ) or $\mathrm{PGI}_{2}$ infusion $\left(1 \mu \mathrm{g} \mathrm{kg}^{-1} \mathrm{~min}^{-1}, 10 \mu 1 \mathrm{~min}^{-1}\right)$ in WT and ApoE-/- mice aged 8-10 and 18-20 weeks. 
Results are expressed in pmol per $10^{9}$ platelets. **: $P<0.01 ; *: P<0.05$ vs vehicle (PBS), injection in the same mouse strain from the same age. $n=5-8$. 
A

ADP: WT

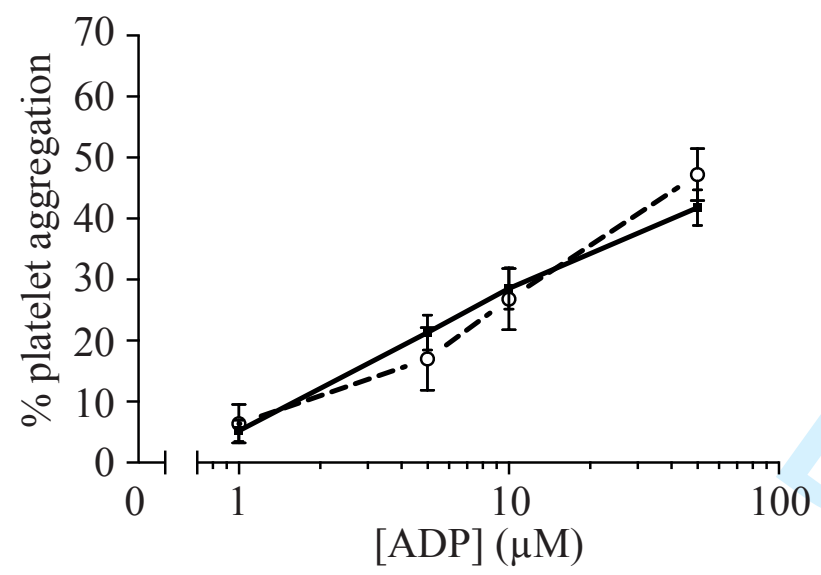

$\mathrm{C}$

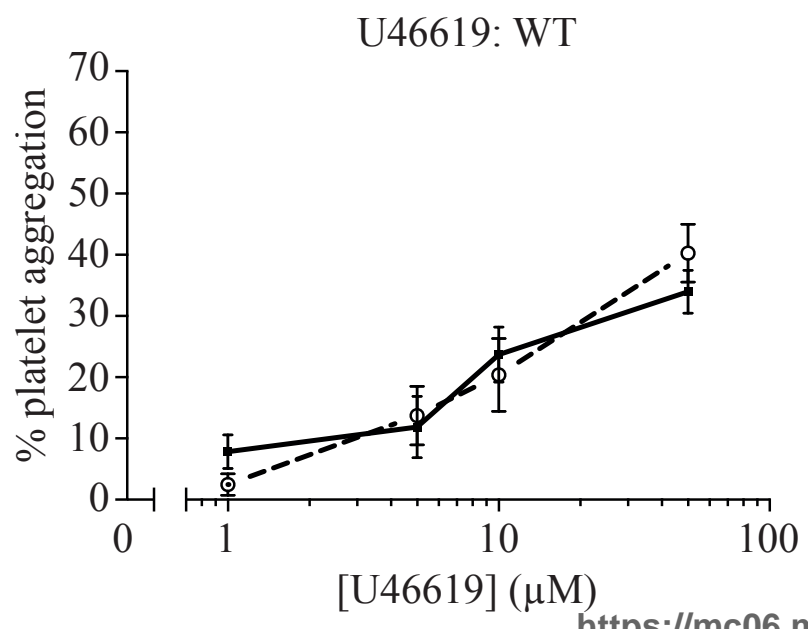

B

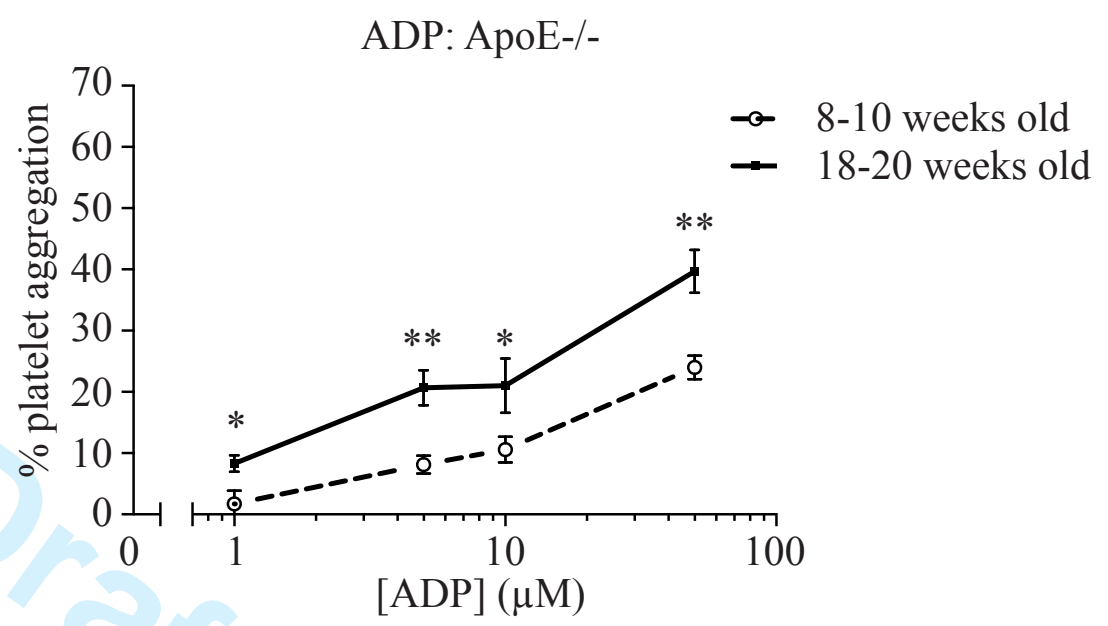

$\mathrm{D}$

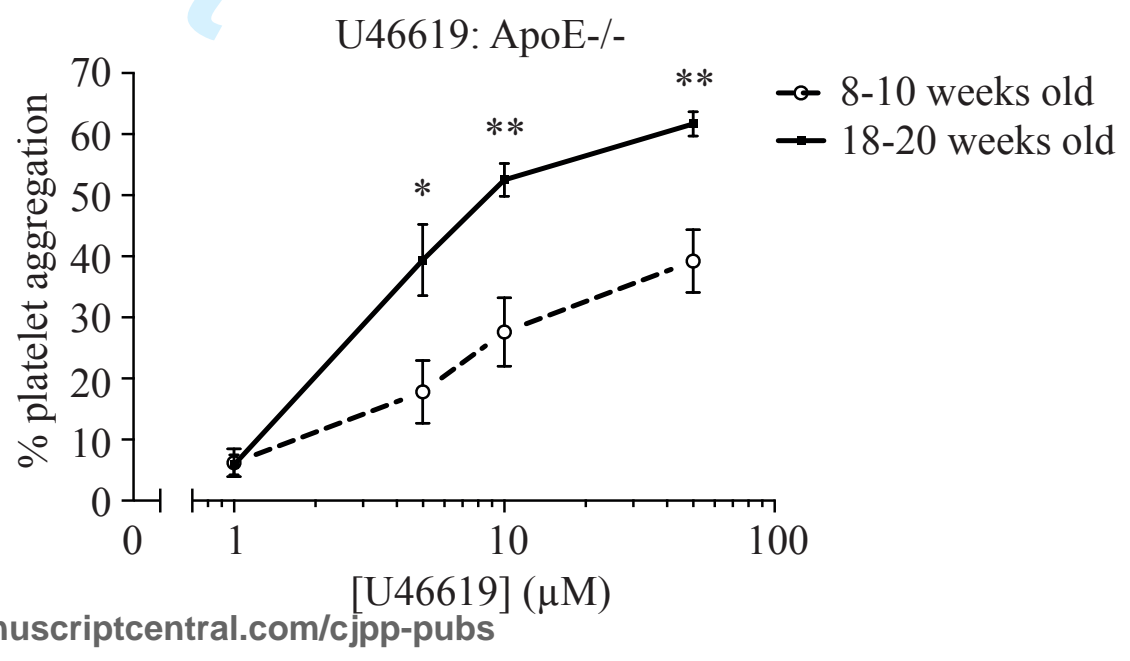




\section{Page 31 of 35}

A

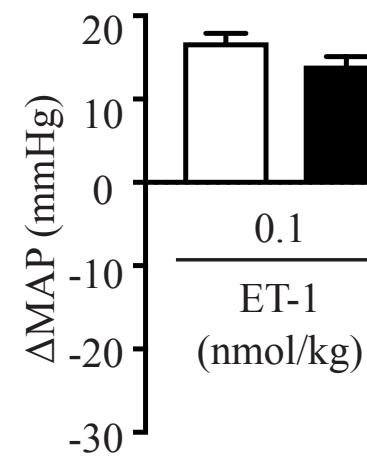

\section{Canadian Journal of Physiology and Pharmacology}

B

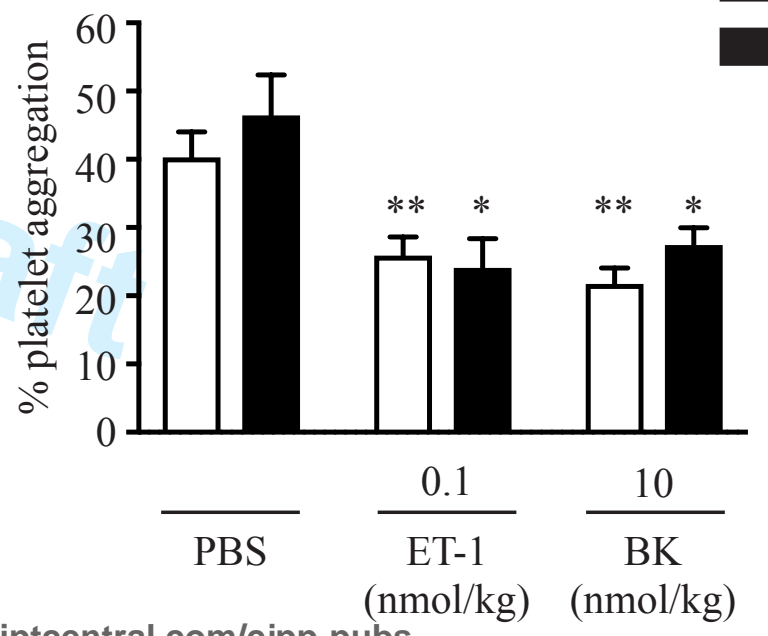

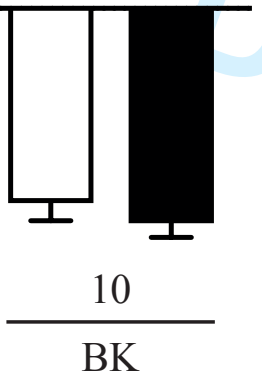

$(\mathrm{nmol} / \mathrm{kg})$
WT

ApoE-/-

https://mc06.manuscriptcentral.com/cjpp-pubs 
A

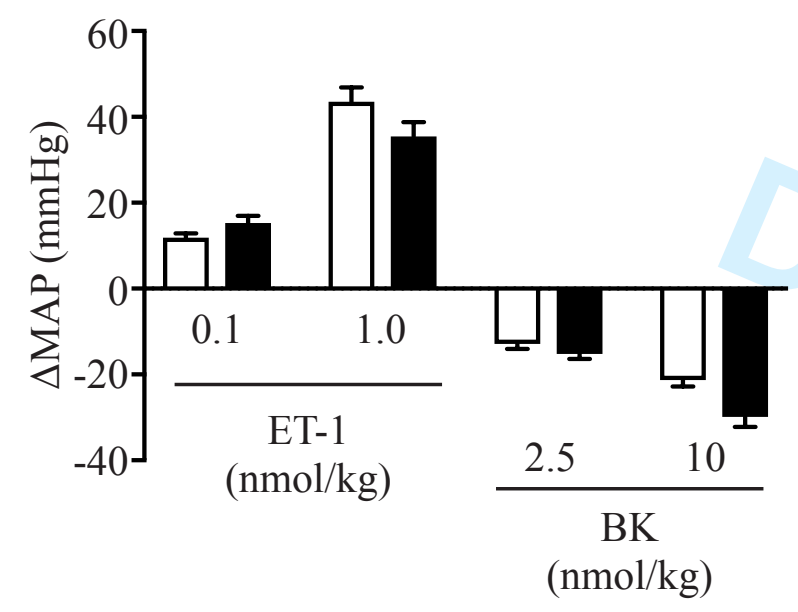

B

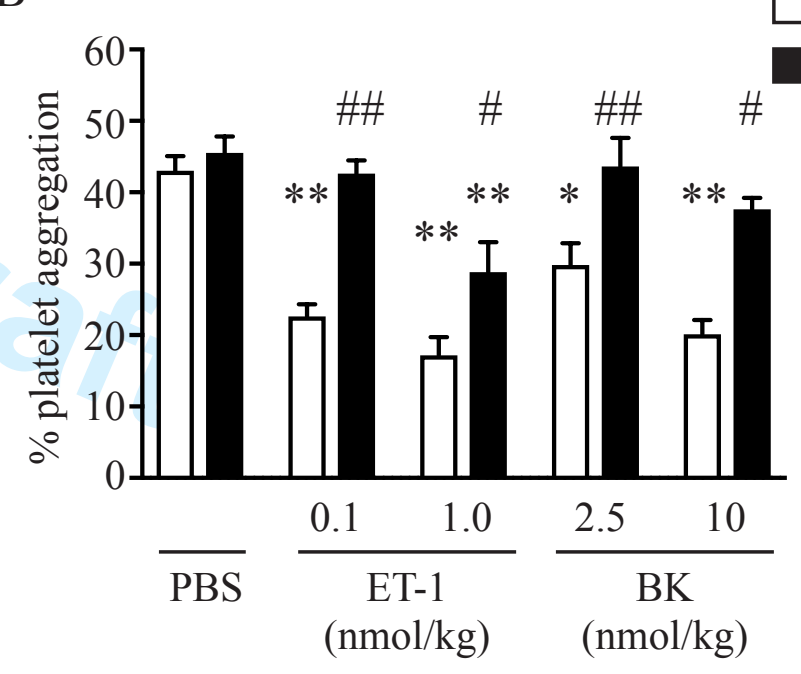

https://mc06.manuscriptcentral.com/cjpp-pubs

Figure 3 


\section{Page 33 of 35}

A

WT

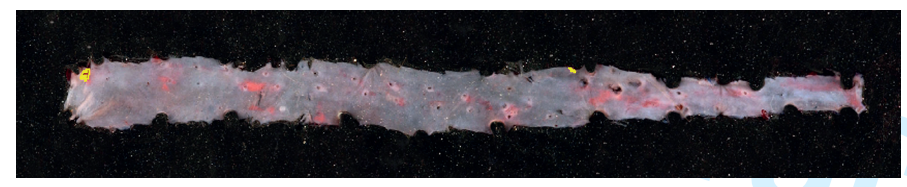

ApoE-/-

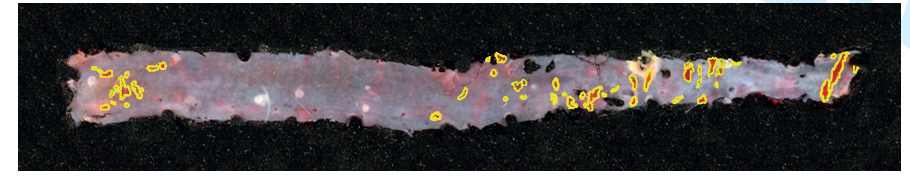

B

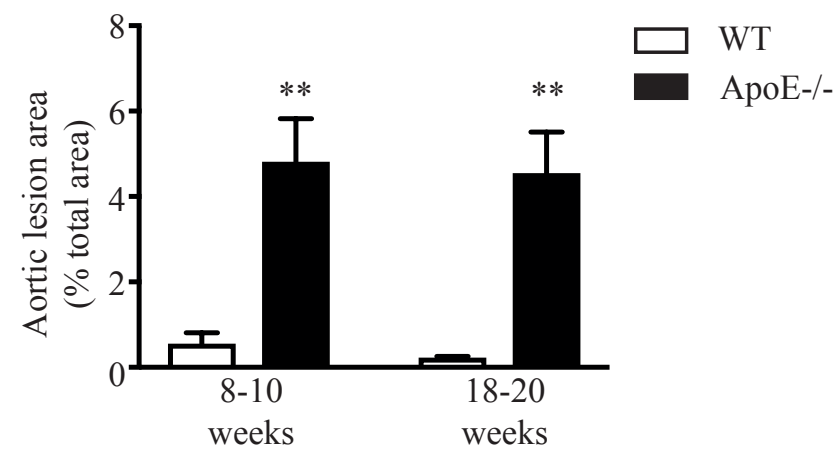

https://mc06.manuscriptcentral.com/cjpp-pubs 


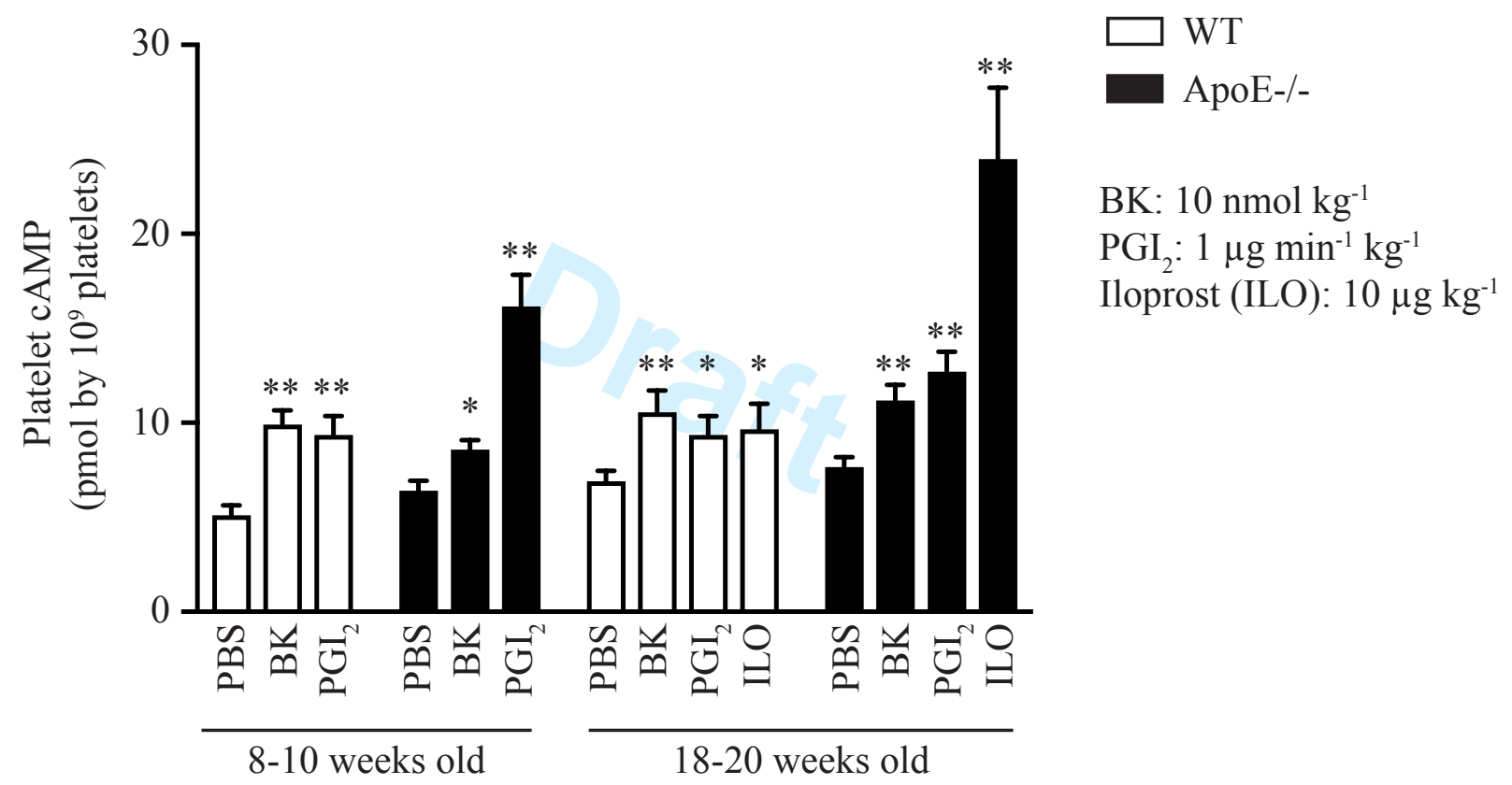

